\title{
Rare Diseases Day and Brain Awareness Week: the active participation of Neurological Sciences
}

\author{
Antonio Federico ${ }^{1}$ \\ Published online: 27 February 2019 \\ (C) Fondazione Società Italiana di Neurologia 2019
}

At the end of February and the beginning of March, two main important manifestations occur:

a) The Rare Disease Day, taking place on the last day of February each year. The main objective of the Rare Disease Day is to raise awareness among the general public and decision-makers about rare diseases and their impact on patients' lives. The campaign targets primarily the general public and also seeks to raise awareness among policy-makers, public authorities, industry representatives, researchers, health professionals, and anyone who has a genuine interest in rare diseases. Rare neurological diseases represent more than $50 \%$ of the global rare diseases, and neurologists have an important role in diagnosis and treatment.

b) The Brain Awareness Week (BAW), March 11-17, 2019, is a yearly global campaign to increase public awareness of the progress and benefits of brain research. Activities include open days at neuroscience labs, exhibitions about the brain, lectures on brain-related topics, social media campaigns, displays at libraries and community centers, classroom workshops, and more.

In order to celebrate these two dates, Neurological Sciences highlights some of the best articles published in between 2017 and 2019 either related to rare neurological diseases or to general clinical neurology, focusing to brain pathogenesis and brain protection. A selection of articles reported in Table 1 and all articles in Table 2 will be set as free access for 1-month time and made publicly available to the neurological scientific community. The whole selection with direct links to article full texts in SpringerLink will be available at https://www.springer.com/10072.

Antonio Federico

federico@unisi.it

Azienda Ospedaliera Universitaria Senese, Viale Bracci 2, 53100 Siena, Italy 
Table 1 A selection of the best articles published in Neurological Sciences in 2017-2019 related to Rare Neurological Diseases

Article title

The diagnosis of dementias: a practical tool not to miss rare causes A case of rapidly progressive dementia: Whipple disease of CNS

What is the role of diffusion tensor imaging (DTI) in detecting subclinical pyramidal tract dysfunction in Behçet's and neuro-Behçet's cases?

Effects of in vivo and in vitro administration of neuro-Behcet's disease IgG

GEN-O-MA project: an Italian network studying clinical course and pathogenic pathways of moyamoya disease - study protocol and preliminary results

Moyamoya masquerading as relapsing remitting multiple sclerosis

Moyamoya complicated by thrombotic cerebrovascular accident in a Caucasian woman with collagenous colitis

A "wavering puff of smoke": a rare case of moyamoya disease

Reversible inflammatory neuropathy superimposed on Charcot-Marie-Tooth type $1 \mathrm{~A}$ disease

Charcot-Marie-Tooth disease: genetic subtypes in the Sardinian population

Long-term therapy with miglustat and cognitive decline in the adult form of Niemann-Pick disease type C: a case report

Dopamine transport system imaging is pathologic in Niemann-Pick type $\mathrm{C}$ - case report

Wilson's disease: a reversible cause of ataxia

Recurrent stroke-like episodes of Wilson disease with a novel Val176fs mutation

A new neurobehavioral phenotype of familial Creutzfeldt-Jakob disease: impaired theory of mind

Sporadic Creutzfeldt-Jakob disease presenting with isolated progressive non-fluent aphasia in a young woman

Aggressive immunosuppression in Susac's syndrome: 10 years of follow-up

Morvan's syndrome - is a pathogen behind the curtain?

Hirayama disease: analysis of cases in Russia

Could Buerger's disease cause nonarteritic anterior ischemic optic neuropathy?: a rare case report

Wernicke encephalopathy and systemic sclerosis: rare association of rare conditions

Clinical variability of children with anti-N-methyl-D-aspartate receptor encephalitis in southern Brazil: a cases series and review of the literature

BK-virus progressive multifocal leukoencephalitis in a patient with systemic lupus erythematosus

Red Flags for early referral of people with symptoms suggestive of narcolepsy: a report from a national multidisciplinary panel

Association between restless legs syndrome and hypertension: a meta-analysis of nine population-based studies

Rate of augmentation and risk factors with long-term follow-up in Japanese patients with restless legs syndrome

The relationship with restless legs syndrome, fibromyalgia, and depressive symptoms in migraine patients

Prevalence of restless legs syndrome in individuals with migraine: a systematic review and meta-analysis of observational studies

Rate of augmentation and risk factors with long-term follow-up in Japanese patients with restless legs syndrome

Italian recommendations for diagnosis and management of congenital myasthenic syndromes

Clinical and CN-SFEMG evaluation of neostigmine test in myasthenia gravis

Whole-exome sequencing reveals a rare interferon gamma receptor

1 mutation associated with myasthenia gravis

Imaging of the thymus in myotonic dystrophy type 1

A rare case of paroxysmal diplopia: ocular neuromyotonia

Late-onset and fast progressive neuropathy and cardiomyopathy in Val32Ala transthyretin gene mutation
Authors (year)

C. Ferrari, B. Nacmias, S. Sorbi (2018) [1]

M.E. Pessa, A. Baldi, G.L. Gigli, et al. (2018) [2]

Seyma Ciftci Aykac, Figen Gökcay, Cem Calli (2019) [3]

E. Erdağ, C. Șahin, C.İ. Küçükali et al. (2018) [4]

A. Bersano, G. Bedini, S. Nava, et al. (2019) [5]

S. Feldman, M. Esch, S. Saidha (2018) [6]

M. Valluri, H. Akhondi, M. Hyndman (2018) [7]

A. Scalise, M. Elena Laino, B. Petralia, et al. (2017) [8]

J. Gazulla, C. Almárcegui, J. Berciano (2018) [9]

L. Lorefice, M.R. Murru, G. Coghe, et al. (2017) [10]

S. Tozza, R. Dubbioso, R. Iodice, et al. (2018) [11]

S. Tomic (2018) [12]

P-W. Ko, K. Kang, H-W. Lee, et al. (2018) [13]

L. Pan, D. Ding, H. Leng, et al. (2018) [14]

A.R. Giovagnoli, G. Tallarita, A. Parente, et al. (2018) [15]

A. Terrin, A. Barp, G. Zanusso, et al. (2017) [16]

E. Capiluppi, L. Romano, S. V. Luccarelli, et al. (2018) [17]

R. Singh, P. Das, U. Kaur, et al. (2018) [18]

A. Rosliakova, I. Zakroyshchikova, I. Bakulin, et al. (2019) [19]

A. Korkmaz, O. Karti, D. Top Karti, et al. (2017) [20]

G. Sciacca, S. Lo Fermo, G. Aprile, et al. (2017) [21]

D. Almeida do Valle, J.S.P. Galeazzi, et al. (2019) [22]

M. Melis, M. Badiali, T. Peltz, et al. (2018) [23]

L. Vignatelli, E. Antelmi, I. Ceretelli, et al. (2018) [24]

Y. Shen, H. Liu, T. Dai, et al. (2018) [25]

K. Tanioka, M. Okura, M. Inoue, et al. (2018) [26]

Z. Akdag Uzun, S. Kurt, H. Karaer Unaldi (2018) [27]

X. Yang, B. Liu, B. Yang, et al. (2018) [28]

K. Tanioka, M. Okura, M. Inoue, et al. (2018) [29]

L. Maggi, P. Bernasconi, A. D’Amico, et al. (2018) [30]

G. Sciacca, Ester Reggio, Giovanni Mostile, et al. (2018) [31]

G. Qi, P. Liu, S. Gu, et al. (2018) [32]

A.Mignarri, F. Gentili, F. Masia, et al. (2018) [33]

M.E. Pessa, L. Verriello, G. Pauletto et al. (2018) [34]

D. Cazzato, E. Dalla Bella, P. Saveri, et al. (2019) [35] 
Table 1 (continued)

Article title Authors (year)

Expert recommendations for diagnosing cervical, oromandibular, and limb dystonia

Clinical presentation and natural history of infantile-onset ascending spastic paralysis from three families with an ALS2 founder variant

Langerhans cell histiocytosis presenting as a rapidly evolving frontotemporal syndrome

A fatal back pain: report of two cases of diffuse large B cell/Burkitt-like nervous system lymphoma

The clinical and imaging features of gray matter heterotopia: a clinical analysis on 15 patients

MR imaging of neoplastic and non-neoplastic lesions of the brain and spine in neurofibromatosis type I

Clinical and genetic characterization of an Italian family with slow-channel syndrome

Ictal kissing: occurrence and etiology

G. Defazio, A. Albanese, R. Pellicciari, et al. (2019) [36]

M. Helal, N. Mazaheri, B. Shalbafan, et al. (2018) [37]

D. Garg, R. Pedapati, T. Nakra, et al. (2019) [38]

I. Markovic, J. Saric Sucic, S. Juric, et al. (2018) [39]

H.K. Raza, H. Chen, T. Chansysouphanthong, et al. (2018) [40]

A.A.K.A. Razek (2018) [41]

C. Angelini, L. Lispi, C. Salvoro, et al. (2018) [42]

A.A. Asadi-Pooya, E.W. Fletman (2017) [43]

Table 2 The most read and cited articles selection for the Brain Awareness Week 2019 (11-17 March). The current year topic is "Protect your brain." These articles will be set as temporary free access

Article title Authors (year)

Unethical human research in the field of neuroscience: a historical review

Benton visual form discrimination test in healthy children: normative data and qualitative analysis

Autism, epilepsy, and synaptopathies: a not rare association

The effect of Wi-Fi electromagnetic waves in unimodal and multimodal object recognition tasks in male rats

Advanced magnetic resonance imaging of neurodegenerative diseases

Multifocal cognitive dysfunction in high-dose benzodiazepine users: a cross-sectional study

Music intervention on cognitive dysfunction in healthy older adults: a systematic review and meta-analysis

Cognitive training in Alzheimer's disease: a controlled randomized study

Microbial treatment: the potential application for Parkinson's disease

alpha-Synuclein in the colon and premotor markers of Parkinson disease in neurologically normal subjects

Estimated prevalence of multiple sclerosis in Italy in 2015

Therapeutic potential of curcumin for multiple sclerosis

The role of deep breathing on stress

Pathogenic mechanisms following ischemic stroke

Effects of robot-assisted upper limb rehabilitation in stroke patients: a systematic review with meta-analysis
H. Algahtani, M. Bajunaid, B. Shirah (2018) [44]

D. Smirni, M. Oliveri, P. Turriziani, et al. (2018) [45]

R. Keller, R. Basta, L. Salerno, et al. (2017) [46]

A. Hassanshahi, S.A. Shafeie, I. Fatemi, et al. (2017) [47]

F. Agosta, S. Galantucci, M. Filippi (2017) [48]

A. Federico, S. Tamburin, A. Maier, et al. (2017) [49]

Bing Xu, Yi Sui, Chunyan Zhu, et al. (2017) [50]

A.R. Giovagnoli, V. Manfredi, A. Parente, et al. (2017) [51]

X. Fang (2019) [52]

Kim Joong-Seok, Park In-Seok, Park, Hyung-Eun, et al. (2017) [53]

M.A. Battaglia, D. Bezzini (2017) [54]

Q. Munibah, A. A-S. Ebtesam, W. Fazli, et al. (2018) [55]

V. Perciavalle, M. Blandini, P. Fecarotta, et al. (2017) [56]

S.E. Khoshnam, W. Winlow, M. Farzaneh, et al. [57]

R. Bertani, C. Melegari, M.C. De Cola, et al. (2017) [58]

. 


\section{Compliance with ethical standards}

Conflict of interest The author declares that he has no conflict of interest.

Publisher's note Springer Nature remains neutral with regard to jurisdictional claims in published maps and institutional affiliations.

\section{References}

1. Ferrari C, Nacmias B, Sorbi S (2018) The diagnosis of dementias: a practical tool not to miss rare causes. Neurol Sci 39:615-627

2. Pessa ME, Baldi A, Gigli GL, Valente M (2018) A case of rapidly progressive dementia: Whipple disease of CNS. Neurol Sci 39: 591-592

3. Aykac SC, Gökcay F, Calli C (2019) What is the role of diffusion tensor imaging (DTI) in detecting subclinical pyramidal tract dysfunction in Behçet's and neuro-Behçet's cases? Neurol Sci. https:// doi.org/10.1007/s 10072-019-3727-9

4. Erdağ E, Șahin C, Küçükali Cİ et al (2017) Effects of in vivo and in vitro administration of neuro-Behcet's disease IgG. Neurol Sci 38:833-843

5. Bersano A, Bedini G, Nava S et al (2019) GEN-O-MA project: an Italian network studying clinical course and pathogenic pathways of moyamoya disease - study protocol and preliminary results. Neurol Sci. https://doi.org/10.1007/s10072-018-3664-Z

6. Feldman S, Esch M, Saidha S (2018) Moyamoya masquerading as relapsing remitting multiple sclerosis. Neurol Sci. https://doi.org/ 10.1007/s10072-018-3615-8

7. Valluri M, Akhondi H, Hyndman M (2018) Moyamoya complicated by thrombotic cerebrovascular accident in a Caucasian woman with collagenous colitis. Neurol Sci 39:2007-2009

8. Scalise A, Laino ME, Petralia B, Piani A, Gigli GL (2017) A "wavering puff of smoke": a rare case of moyamoya disease. Neurol Sci 38:2073-2074

9. Gazulla J, Almárcegui C, Berciano J (2018) Reversible inflammatory neuropathy superimposed on Charcot-Marie-Tooth type 1A disease. Neurol Sci 39:793-794

10. Lorefice L, Murru MR, Coghe G, Fenu G, Corongiu D, Frau J, Tranquilli S, Tacconi P, Vannelli A, Marrosu G, Mamusa E, Cocco E, Marrosu MG (2017) Charcot-Marie-Tooth disease: genetic subtypes in the Sardinian population. Neurol Sci 38:10191025

11. Tozza S, Dubbioso R, Iodice R, Topa A, Esposito M, Ruggiero L, Spina E, de Rosa A, Saccà F, Santoro L, Manganelli F (2018) Longterm therapy with miglustat and cognitive decline in the adult form of Niemann-Pick disease type C: a case report. Neurol Sci 39:10151019

12. Tomic S (2018) Dopamine transport system imaging is pathologic in Niemann-Pick type C—case report. Neurol Sci 39:1139-1140

13. Ko PW, Kang K, Lee HW (2018) Wilson's disease: a reversible cause of ataxia. Neurol Sci 39:2001-2002

14. Pan L, Ding D, Leng H, Deng X, Xu Y (2018) Recurrent stroke-like episodes of Wilson disease with a novel Val176fs mutation. Neurol Sci 39:973-974

15. Giovagnoli AR, Tallarita G, Parente A, del Sole A, di Fede G (2018) A new neurobehavioral phenotype of familial CreutzfeldtJakob disease: impaired theory of mind. Neurol Sci. https://doi.org/ 10.1007/s10072-018-3646-1

16. Terrin A, Barp A, Zanusso G, Gallo P, Cagnin A (2017) Sporadic Creutzfeldt-Jakob disease presenting with isolated progressive nonfluent aphasia in a young woman. Neurol Sci 38:1535-1537
17. Capiluppi E, Romano L, Luccarelli SV, Macerollo A, Cislaghi G (2018) Aggressive immunosuppression in Susac's syndrome: 10 years of follow-up. Neurol Sci 39:1807-1809

18. Singh R, Das P, Kaur U, Misra A, Choudhury A, Manna S, Gaude R, Gautam D, Gambhir IS, Chakrabarti SS (2018) Morvan's syndrome-is a pathogen behind the curtain? Neurol Sci 39: 1965-1969

19. Rosliakova A, Zakroyshchikova I, Bakulin I, Konovalov R, Kremneva E, Krotenkova M, Suponeva N, Zakharova M (2019) Hirayama disease: analysis of cases in Russia. Neurol Sci 40:105112

20. Korkmaz A, Karti O, Top Karti D, Yüksel B, Zengin MO, Kusbeci $\mathrm{T}$ (2018) Could Buerger's disease cause nonarteritic anterior ischemic optic neuropathy?: a rare case report. Neurol Sci 39:1309-1312

21. Sciacca G, Fermo SL, Aprile G, Nicoletti A, Zappia M (2017) Wernicke encephalopathy and systemic sclerosis: rare association of rare conditions. Neurol Sci 38:203-2015

22. Almeida do Valle D, Galeazzi JSP, de Rezende Machado $\mathrm{M}$ et al (2019) Clinical variability of children with anti-N-methyl-Daspartate receptor encephalitis in southern Brazil: a cases series and review of the literature. Neurol Sci 40:351-356

23. Melis M, Badiali M, Peltz T, Cossu G, Manieli C, Gianno F, Melis M (2018) BK-virus progressive multifocal leukoencephalitis in a patient with systemic lupus erythematosus. Neurol Sci 39:16131615

24. Vignatelli L, Antelmi E, Ceretelli I, Bellini M, Carta C, Cortelli P, Ferini-Strambi L, Ferri R, Guerrini R, Ingravallo F, Marchiani V, Mari F, Pieroni G, Pizza F, Verga MC, Verrillo E, Taruscio D, Plazzi G (2018) Red Flags for early referral of people with symptoms suggestive of narcolepsy: a report from a national multidisciplinary panel. Neurol Sci. https://doi.org/10.1007/s10072-018-3666-X

25. Shen Y, Liu H, Dai T, Guan Y, Tu J, Nie H (2018) Association between restless legs syndrome and hypertension: a meta-analysis of nine population-based studies. Neurol Sci 39:235-242

26. Tanioka K, Okura M, Inoue M, Taniguchi KI, Taniguchi M, Hamano T, Tachibana N (2018) Rate of augmentation and risk factors with long-term follow-up in Japanese patients with restless legs syndrome. Neurol Sci 39:1559-1564

27. Akdag Uzun Z, Kurt S, Karaer Unaldi H (2018) The relationship with restless legs syndrome, fibromyalgia, and depressive symptoms in migraine patients. Neurol Sci 39:1409-1414

28. Yang X, Liu B, Yang B, Li S, Wang F, Li K, Hu F, Ren H, Xu Z (2018) Prevalence of restless legs syndrome in individuals with migraine: a systematic review and meta-analysis of observational studies. Neurol Sci 39:1927-1934

29. Tanioka K, Okura M, Inoue M et al (2018) Rate of augmentation and risk factors with long-term follow-up in Japanese patients with restless legs syndrome. Neurol Sci 39:15591564

30. Maggi L, Bernasconi P, D'Amico A et al (2018) Italian recommendations for diagnosis and management of congenital myasthenic syndromes. Neurol Sci 39:1559-1564. https://doi.org/10.1007/ s10072-018-3456-5

31. Sciacca G, Reggio E, Mostile G, Nicoletti A, Drago F, Salomone S, Zappia M (2018) Clinical and CN-SFEMG evaluation of neostigmine test in myasthenia gravis. Neurol Sci 39:341-345

32. Qi G, Liu P, Gu S, Yang H, Dong H, Xue Y (2018) Whole-exome sequencing reveals a rare interferon gamma receptor 1 mutation associated with myasthenia gravis. Neurol Sci 39:717-724

33. Mignarri A, Gentili F, Masia F, Genua A, Cenciarelli S, Brunori P, Mazzei MA, Malandrini A, Federico A, Mazzei FG, Dotti MT (2018) Imaging of the thymus in myotonic dystrophy type 1 . Neurol Sci 39:347-351

34. Pessa ME, Verriello L, Pauletto G, Gigli GL, Valente M (2018) A rare case of paroxysmal diplopia: ocular neuromyotonia. Neurol Sci 39:1785-1786 
35. Cazzato D, Dalla Bella E, Saveri P, Taroni F, Marucci G, Lauria G (2019) Late-onset and fast progressive neuropathy and cardiomyopathy in Val32Ala transthyretin gene mutation. Neurol Sci. https:// doi.org/10.1007/s10072-019-3716-Z

36. Defazio G, Albanese A, Pellicciari R, Scaglione CL, Esposito M, Morgante F, Abbruzzese G, Bentivoglio AR, Bono F, Coletti Moja M, Fabbrini G, Girlanda P, Lopiano L, Pacchetti C, Romano M, Fadda L, Berardelli A (2019) Expert recommendations for diagnosing cervical, oromandibular, and limb dystonia. Neurol Sci 40:8995

37. Helal M, Mazaheri N, Shalbafan B, Malamiri RA, Dilaver N, Buchert R, Mohammadiasl J, Golchin N, Sedaghat A, Mehrjardi MYV, Haack TB, Riess O, Chung WK, Galehdari H, Shariati G, Maroofian R (2018) Clinical presentation and natural history of infantile-onset ascending spastic paralysis from three families with an ALS2 founder variant. Neurol Sci 39:1917-1925

38. Garg D, Pedapati R, Nakra T, Singh RK, Prabhakar A, Dash D, Bhatia R, Tripathi M (2019) Langerhans cell histiocytosis presenting as a rapidly evolving frontotemporal syndrome. Neurol Sci. https://doi.org/10.1007/s10072-019-3709-y

39. Markovic I, Saric Sucic J, Juric S, Titlic M, Basic S (2018) A fatal back pain: report of two cases of diffuse large B cell/Burkitt-like nervous system lymphoma. Neurol Sci. https://doi.org/10.1007/ s10072-018-3631-8

40. Raza HK, Chen H, Chansysouphanthong T, Zhang Z, Hua F, Ye X, Zhang W, Dong L, Zhang S, Wang X, Cui G (2018) The clinical and imaging features of gray matter heterotopia: a clinical analysis on 15 patients. Neurol Sci. https://doi.org/10.1007/s10072-0183667-9

41. Razek AAKA (2018) MR imaging of neoplastic and non-neoplastic lesions of the brain and spine in neurofibromatosis type I. Neurol Sci 39:821-827

42. Angelini C, Lispi L, Salvoro C, Mostacciuolo ML, Vazza G (2018) Clinical and genetic characterization of an Italian family with slowchannel syndrome. Neurol Sci. https://doi.org/10.1007/s10072018-3645-2

43. Asadi-Pooya AA, Fletman EW (2017) Ictal kissing: occurrence and etiology. Neurol Sci 38:353-355

44. Algahtani H, Bajunaid M, Shirah B (2018) Unethical human research in the field of neuroscience: a historical review. Neurol Sci 39:829-834
45. Smirni D, Oliveri M, Turriziani P, di Martino G, Smirni P (2018) Benton visual form discrimination test in healthy children: normative data and qualitative analysis. Neurol Sci 39:885-892

46. Keller R, Basta R, Salerno L, Elia M (2017) Autism, epilepsy, and synaptopathies: a not rare association. Neurol Sci 38:1353-1361

47. Hassanshahi A, Shafeie SA, Fatemi I, Hassanshahi E, Allahtavakoli M, Shabani M, Roohbakhsh A, Shamsizadeh A (2017) The effect of Wi-Fi electromagnetic waves in unimodal and multimodal object recognition tasks in male rats. Neurol Sci 38:1069-1076

48. Agosta F, Galantucci S, Filippi M (2017) Advanced magnetic resonance imaging of neurodegenerative diseases. Neurol Sci 38:4151

49. Federico A, Tamburin S, Maier A, Faccini M, Casari R, Morbioli L, Lugoboni F (2017) Multifocal cognitive dysfunction in high-dose benzodiazepine users: a cross-sectional study. Neurol Sci 38:137142

50. Xu B, Sui Y, Zhu C et al (2017) Music intervention on cognitive dysfunction in healthy older adults: a systematic review and metaanalysis. Neurol Sci 38:983-992

51. Giovagnoli AR, Manfredi V, Parente A, Schifano L, Oliveri S, Avanzini G (2017) Cognitive training in Alzheimer's disease: a controlled randomized study. Neurol Sci 38(8):1485-1493

52. Fang X (2019) Microbial treatment: the potential application for Parkinson's disease. Neurol Sci 40:51-58

53. Kim J-S, Park I-S, Park H-E et al (2017) Alpha-Synuclein in the colon and premotor markers of Parkinson disease in neurologically normal subjects. Neurol Sci 38:171-179

54. Battaglia MA, Bezzini D (2017) Estimated prevalence of multiple sclerosis in Italy in 2015. Neurol Sci 38:473-479

55. Munibah Q, Ebtesam AA-S, Fazli W et al (2018) Therapeutic potential of curcumin for multiple sclerosis. Neurol Sci 39:207-214

56. Perciavalle V, Blandini M, Fecarotta P, Buscemi A, di Corrado D, Bertolo L, Fichera F, Coco M (2017) The role of deep breathing on stress. Neurol Sci 38:451-458

57. Khoshnam SE, Winlow W, Farzaneh M, Farbood Y, Moghaddam HF (2017) Pathogenic mechanisms following ischemic stroke. Neurol Sci 38:1167-1186

58. Bertani R, Melegari C, De Cola MC et al (2017) Effects of robotassisted upper limb rehabilitation in stroke patients: a systematic review with meta-analysis. Neurol Sci 38:1561-1569 